Review

\title{
New emerging viral infections in human beings that first appeared in Asia: a summary for the present decade $2001-2010$
}

\author{
Viroj Wiwanitkit \\ Visiting University Professor, Hainan Medical University, China; Wiwanitkit House, Bangkhae, Bangkok 10160, Thailand
}

\begin{abstract}
Emerging infectious diseases are usually a public concern. The presence of new emerging infectious diseases is a topic to be reported on and discussed about in medicine. Several new emerging infectious diseases have occurred within the present decade. In this specific review, the author briefly reviews the important new emerging human viral infections that first appeared in Asia during the present decade, $2001-2010$.
\end{abstract}

Keywords Asia, emerging, virus, infection

\section{INTRODUCTION}

Infection is an important pathological in medicine. It is one of the most common medical disorders for human beings and can be seen everywhere around the world. The occurrence of new infections in new settings is considered important in epidemiology. This condition is called an emerging infectious disease.

Emerging infectious diseases are usually a public concern. The presence of new emerging infectious diseases is a topic to be reported and discussed in medicine (Wiwanitkit, 2011). Several new emerging infectious diseases have occurred within the present decade. Any pathogen, virus, bacteria, fungi, and parasite can be the cause of the new emerging infectious disease. However, the new emerging viral infections are usually of special consideration due to their nature as hard-totreat agents of the viruses.

In Asia, the large number of local populations living in poor and developing conditions lead to the susceptibility to infection (Coker et al., 2011). The occurrence of the new emerging infection in these areas seems to be a common problem. In this specific review, the author briefly reviews the important new emerging human viral infections first occurring in Asia in the present decade, 2001 - 2010.

\section{SARS}

Severe acute respiratory syndrome (SARS) is a new viral emerging infectious disease first appearing in Asia. It spread globally in a matter of weeks due to the close contact of index infective patients (Hughes, 2004). The first report of SARS was from China (in March 2003) and the causative agent was finally identified as a novel coronavirus, SARS-coronavirus (Christian et al., 2004). Within the first one year of its emerging, this virus spread around the world and caused the disease in 8098 people in 26 countries, killing 774 of them (Christian et al., 2004). This disease was finally listed as an important zoonosis (Wang and Eaton, 2007). The first outbreak is believed to be due to the virus from palm civet (Paguma

*Correspondence: Viroj Wiwanitkit

E-mail: wviroj@yahoo.com

Received June 2, 2011; Accepted November 22, 2011; Published November 30, 2011

doi: http://dx.doi.org/10.5677/tang.2011.0007

C2011 by Association of Humanitas Medicine larvata) (Zhao, 2007).

In 2003, Marra et al. (2003) from a British study group successfully identified the genomic structure of the pathogen revealing 29,751-base and found that this new virus was "only moderately related to other known coronaviruses, including two human coronaviruses, HCoV-OC43 and HCoV-229E." Another similar published data from a USA study group reported that the complete genome of SARS-CoV had 29,727 nucleotides in length and has 11 open reading frames (Rota et al., 2003). There are several continuous reports on the structure of this new virus attempting to find the treatment method. An interesting report is on its proteomic structure that can be the target for drug development. Kuhn et al. (2007) concluded that angiotensin-converting enzyme 2 (ACE2) was an obligate cellular receptor for the virus and proposed that the two main targets of antiviral therapeutics include "the SARS-CoV spike protein and ACE2".

Focusing on the clinical presentation of this new infection, the severe respiratory impairment and distress is common (Chan et al., 2006). One-fifth of the cases usually require management in intensive care units (Booth and Stewart, 2005). The infection results in a high fatality rate, and the common cause of death is acute respiratory distress syndrome (Booth and Stewart, 2005). The presence of a comorbid disease and the severity of the illness at presentation are the two main predictors for the outcome of SARS (Booth and Stewart, 2005). However, the clinical picture is significantly less severe for pediatric patients (Leung and Chiu, 2004). For the diagnosis, the standard method is usually by a reverse transcriptionpolymerase chain reaction (RT-PCR) assays with a reported sensitivity up to $80 \%$ in the first 3 days of illness (Booth and Stewart, 2005). The specimen for diagnosis is nasopharyngeal aspirate (Booth and Stewart, 2005). Focusing on the chest $\mathrm{x}$ rays, there is no significant finding which can differentially diagnose SARS from other pathological conditions that can cause the respiratory distress pattern. The diffuse alveolar damage is common (Ketai et al., 2006). Focusing on the basic blood test, it is shown that "SARS is a viral-induced lymphopenia disease" (Wiwanitkit, 2007). A profound CD4+ and $\mathrm{CD} 8+$ lymphopenia is the predictor for a severe clinical outcome (He et al., 2005).

Concerning the treatment, there is still no specific antiviral therapy for this infection (Anderson and Tong, 2010). The 
symptomatic treatment is used (Hui and Chan, 2010). There is also no specific SARS vaccine at present.

\section{Bird flu}

Bird flu or avian influenza is another important well-known viral infection that was first reported in Asia. This human infection is a newly detected respiratory tract infection. The disease was first seen in an outbreak in animals, avian in Asia. However, after the outbreak in poultry, the first outbreak of the highly pathogenic avian influenza H5N1 occurred in Hong Kong in 1997 (Hatta and Kawaoka, 2002) and repeatedly occurred in some Asian countries especially in Vietnam and Thailand in 2003 (Trampuz et al., 2004). The infection presents as a severe respiratory tract infection. Pneumonia is common and the fatality rate is high compared to simple influenza (Wiwanitkit, 2006). The death rate is up to $60 \%$ (Guan et al., 2009).

The disease is considered to be a zoonosis. The pathogen is the newly identified H5N1 influenza virus. Most cases are due to exposure to sick poultry (Van Kerkhove et al., 2011). The reported risk exposures include "contact with infected blood or bodily fluids of infected poultry via food preparation practices", "touching and caring for infected poultry; consuming uncooked poultry products", "exposure to $\mathrm{H} 5 \mathrm{~N} 1$ via swimming or bathing in potentially virus laden ponds" and "exposure to H5N1 at live bird markets" (Van Kerkhove et al., 2011). Existing evidence shows that wild birds can become infected from domestic poultry and potentially can exchange viruses when they share the same environment, and those infected wild birds are the carriers of the virus to new distanced settings (Sims et al., 2005).

Focusing on the pathogenic virus, it is classified as "an antigenic variant of the $Z$ genotype" (Webster et al., 2005). According to the molecular virology study, it is detected that "only the M2 and PB1-F2 genes were under positive selection, suggesting that these genes might be involved in adaptation of this virus to new hosts following interspecies transmission (Smith et al., 2006)". The clinical presentation of the infected cases is similar to that of SARS; however, it has a wider range of severity. It can be an asymptomatic infection or mild influenza-like illness or severe pneumonia with multi-organ failure (Hui, 2008). In addition, extra-respiratory signs and symptoms can be detected. Diarrhea is common (Wiwanitkit, 2005). Focusing on laboratory findings, several blood abnormalities can be detected. Thrombocytopenia, disturbance of hemostatic system, abnormal white blood count, impairment of CD4 and CD8 are the good examples (Wiwanaitkit, 2008a, 2008b). Focusing on chest x-rays, several findings are reports including multi-focal airspace consolidation, interstitial infiltrates, patchy or lobar involvement, with a rapid progression to bilateral and diffuse ground-glass opacities (Hui, 2008). Concerning the treatment, the antiviral therapy for classical influenza can be applied for this infection; however, there is still no conclusive appropriate effective regimen (Beigel and Bray, 2008). Cinatl et al. (2007) proposed that "Dosage increase, prolonged treatment or combination therapies may increase treatment efficacy and/or inhibit resistance." There is also no specific human vaccine at present.

After the emergence on this atypical viral infection, another attack by a new respiratory virus also came to Asia from the origin in Mexico. However, this is not a disease that was first detected in human cases in Asia, hence, it is hereby not discussed in detail.

\section{Nippah virus infection}

Nippah virus infection is a kind of encephalitis virus infection. This infection was first described in Malaysia (Lam and Chua,
2002). It is believed to be zoonosis from pig. The pathogenic virus is classified into a paramyxoviral group. The clinical presentation of nippah virus is the classical findings in general encephalitis including segmental myoclonus, areflexia, hypertension, and tachycardia (Lam and Chua, 2002). Some cases can be asymptomatic. Focusing on magnetic resonance imaging of the brain, the presence of discrete high-signalintensity lesions disseminated throughout the brain is common (Lam and Chua, 2002). "Small lesions that are primarily within the white matter, with transient punctate cortical hyperintensities on T1-weighted images (Lim et al., 2002)" is the radiological hallmark. This disease has been determined for more than one decade and still be an important problem in Southeast Asia (Wong et al., 2002). Since it is not a newly identified virus within the past decade, it is hereby not discussed in detail.

\section{Novel bunya virus infection}

The novel bunya virus infection might be the newest emerging infectious disease in Asia. The virus has just been discovered and reported from China in April 2011. It can be identified in the patients with a severe fever with thrombocytopenia syndrome (Yu et al., 2011). The patient usually presents with a fever, thrombocytopenia, leukocytopenia, and multiorgan dysfunction (Yu et al., 2011). Since this is the very new emerging infectious disease, the data is very limited. It should be the focus for the future research. Indeed, the hemorrhagic fever is very common in Asia and the exact cause is usually under investigated.

\section{CONCLUSION}

In the past decade, $2001-2010$, there have been many new emerging infectious diseases appearing in Asia. These diseases are usually problematic and cause public health problems in general. The attempt to learn the natures of those diseases and finding the proper diagnostic, therapeutic and preventive managements is important. To monitor for possible new emerging infectious diseases in this area is necessary.

\section{CONFLICT OF INTEREST}

The authors have no conflicting financial interests.

\section{REFERENCES}

Anderson LJ, Tong S. Update on SARS research and other possibly zoonotic coronaviruses. Int $\mathrm{J}$ Antimicrob Agents. 2010;36:S21-S25.

Beigel J, Bray M. Current and future antiviral therapy of severe seasonal and avian influenza. Antiviral Res. 2008;78:91-102.

Booth CM, Stewart TE. Severe acute respiratory syndrome and critical care medicine: the Toronto experience. Crit Care Med. 2005;33:S53-S60.

Chan PK, Tang JW, Hui DS. SARS: clinical presentation, transmission, pathogenesis and treatment options. Clin Sci (Lond). 2006;110:193-204.

Christian MD, Poutanen SM, Loutfy MR, Muller MP, Low DE. Severe acute respiratory syndrome. Clin Infect Dis. 2004;38:1420-1427. 
Cinatl J Jr, Michaelis M, Doerr HW. The threat of avian influenza A (H5N1). Part III: Antiviral therapy. Med Microbiol Immunol. 2007;196:203-212.

Coker RJ, Hunter BM, Rudge JW, Liverani M, Hanvoravongchai P. Emerging infectious diseases in southeast Asia: regional challenges to control. Lancet. 2011;377:599-609.

Guan Y, Smith GJ, Webby R, Webster RG. Molecular epidemiology of $\mathrm{H} 5 \mathrm{~N} 1$ avian influenza. Rev Sci Tech. 2009;28:39-47.

Hatta M, Kawaoka Y. The continued pandemic threat posed by avian influenza viruses in Hong Kong. Trends Microbiol. 2002;10:340-344.

He Z, Zhao C, Dong Q, Zhuang H, Song S, Peng G, Dwyer DE. Effects of severe acute respiratory syndrome (SARS) coronavirus infection on peripheral blood lymphocytes and their subsets. Int J Infect Dis. 2005;9:323-330.

Hughes JM. SARS: an emerging global microbial threat. Trans Am Clin Climatol Assoc. 2004;115:361-372.

Hui DS. Review of clinical symptoms and spectrum in humans with influenza A/H5N1 infection. Respirology. 2008;13:S10S13.

Hui DS, Chan PK. Severe acute respiratory syndrome and coronavirus. Infect Dis Clin North Am. 2010;24:619-638.

Ketai L, Paul NS, Wong KT. Radiology of severe acute respiratory syndrome (SARS): the emerging pathologicradiologic correlates of an emerging disease. J Thorac Imaging. 2006;21:276-283.

Kuhn JH, Li W, Radoshitzky SR, Choe H, Farzan M. Severe acute respiratory syndrome coronavirus entry as a target of antiviral therapies. Antivir Ther. 2007;12:639-650.

Lam SK, Chua KB. Nipah virus encephalitis outbreak in Malaysia. Clin Infect Dis. 2002;34:S48-S51.

Leung CW, Chiu WK. Clinical picture, diagnosis, treatment and outcome of severe acute respiratory syndrome (SARS) in children. Paediatr Respir Rev. 2004;5:275-288.

Lim CC, Lee KE, Lee WL, Tambyah PA, Lee CC, Sitoh YY, Auchus AP, Lin BK, Hui F. Nipah virus encephalitis: serial MR study of an emerging disease. Radiology. 2002;222:219226.

Marra MA, Jones SJ, Astell CR, Holt RA, Brooks-Wilson A, Butterfield YS, Khattra J, Asano JK, Barber SA, Chan SY, Cloutier A, Coughlin SM, Freeman D, Girn N, Griffith OL, Leach SR, Mayo M, McDonald H, Montgomery SB, Pandoh PK, Petrescu AS, Robertson AG, Schein JE, Siddiqui A, Smailus DE, Stott JM, Yang GS, Plummer F, Andonov A, Artsob H, Bastien N, Bernard K, Booth TF, Bowness D, Czub M, Drebot M, Fernando L, Flick R, Garbutt M, Gray M, Grolla A, Jones S, Feldmann H, Meyers A, Kabani A, Li Y, Normand S, Stroher U, Tipples GA, Tyler S, Vogrig R, Ward D, Watson B, Brunham RC, Krajden M, Petric M, Skowronski DM, Upton C, Roper RL. The Genome sequence of the SARS-associated coronavirus. Science. 2003;300:1399-1404.
Rota PA, Oberste MS, Monroe SS, Nix WA, Campagnoli R, Icenogle JP, Peñaranda S, Bankamp B, Maher K, Chen MH, Tong S, Tamin A, Lowe L, Frace M, DeRisi JL, Chen Q, Wang D, Erdman DD, Peret TC, Burns C, Ksiazek TG, Rollin PE, Sanchez A, Liffick S, Holloway B, Limor J, McCaustland K, Olsen-Rasmussen M, Fouchier R, Günther S, Osterhaus AD, Drosten C, Pallansch MA, Anderson LJ, Bellini WJ. Characterization of a novel coronavirus associated with severe acute respiratory syndrome. Science. 2003;300:1394-1399.

Sims LD, Domenech J, Benigno C, Kahn S, Kamata A, Lubroth J, Martin V, Roeder P. Origin and evolution of highly pathogenic H5N1 avian influenza in Asia. Vet Rec. 2005; 157:159-164.

Smith GJ, Naipospos TS, Nguyen TD, de Jong MD, Vijaykrishna D, Usman TB, Hassan SS, Nguyen TV, Dao TV, Bui NA, Leung YH, Cheung CL, Rayner JM, Zhang JX, Zhang LJ, Poon LL, Li KS, Nguyen VC, Hien TT, Farrar J, Webster RG, Chen H, Peiris JS, Guan Y. Evolution and adaptation of H5N1 influenza virus in avian and human hosts in Indonesia and Vietnam. Virology. 2006;350:258-268.

Trampuz A, Prabhu RM, Smith TF, Baddour LM. Avian influenza: a new pandemic threat?. Mayo Clin Proc. 2004;79:523-530.

Van Kerkhove MD, Mumford E, Mounts AW, Bresee J, Ly S, Bridges CB, Otte J. Highly pathogenic avian influenza (H5N1): pathways of exposure at the animal-human interface, a systematic review. PLoS One. 2011;6:e14582.

Wang LF, Eaton BT. Bats, civets and the emergence of SARS. Curr Top Microbiol Immunol. 2007;315:325-344.

Webster RG, Guan Y, Poon L, Krauss S, Webby R, Govorkovai E, Peiris M. The spread of the H5N1 bird flu epidemic in Asia in 2004. Arch Virol Suppl. 2005;117-129.

Wiwanitkit V. Diarrhoea as a presentation of bird flu infection: a summary on its correlation to outcome in Thai cases. Gut. 2005;54:1506.

Wiwanitkit V. A typical bird flu infection, caused by the H5N1 virus, is a new emerging infectious disease. $\mathrm{J}$ Trauma. 2006;61:768-769.

Wiwanitkit V. Lymphopenia in severe acute respiratory syndrome: a summary on its frequency. Nepal Med Coll J. 2007;9:132-133

Wiwanitkit V. Leucocyte and lymphocyte count in cases of bird flu infection in Thailand. J Indian Med Assoc. 2008;106:168, 186.

Wiwanitkit V. Hemostatic disorders in bird flu infection. Blood Coagul Fibrinolysis. 2008;19:5-6.

Wiwanitkit V. The usefulness of case reports in managing emerging infectious disease. J Med Case Reports. 2011;5:194.

Wong KT, Shieh WJ, Zaki SR, Tan CT. Nipah virus infection, an emerging paramyxoviral zoonosis. Springer Semin Immunopathol. 2002;24:215-228.

Yu XJ, Liang MF, Zhang SY, Liu Y, Li JD, Sun YL, Zhang L, Zhang QF, Popov VL, Li C, Qu J, Li Q, Zhang YP, Hai R, Wu 
W, Wang Q, Zhan FX, Wang XJ, Kan B, Wang SW, Wan KL, Jing HQ, Lu JX, Yin WW, Zhou H, Guan XH, Liu JF, Bi ZQ, Liu GH, Ren J, Wang H, Zhao Z, Song JD, He JR, Wan T, Zhang JS, Fu XP, Sun LN, Dong XP, Feng ZJ, Yang WZ, Hong T, Zhang Y, Walker DH, Wang Y, Li DX. Fever with thrombocytopenia associated with a novel bunyavirus in China. NEJM. 2011;364:1523-1532.
Zhao GP. SARS molecular epidemiology: a Chinese fairy tale of controlling an emerging zoonotic disease in the genomics era. Philos Trans R Soc Lond B Biol Sci. 2007;362:1063-1081. 